\title{
Developing technology acceptance models for decision making in urban management
}

\begin{abstract}
Technology adoption concept refers to a complicated process covering people, technology and the implementation context. In this paper, we (1) review some of the most reliable technology acceptance models such as Technology Acceptance Model (TAM) and its recent versionsTAM2 and 3; (2) review their constructs, and finally (3) discuss differences of those models. The review shows that TAM still needs further development to be applied to transportation and urban planning disciplines. The models are thoroughly discussed how they can be extended in a way to cover transportation, urban planning and infrastructure management disciplines. TAM is extended by additional variables to produce TAM3 as a comprehensive model in information systems, but there is not any evidence showing that the model can be a reliable predictive model for other disciplines.
\end{abstract}

Volume 2 Issue $6-2017$

\author{
Sharifeh Sargolzaei \\ Faculty of Urban Planning, Art University of Isfahan, Iran
}

Correspondence: Sharifeh Sargolzaei, Faculty of Urban Planning, Art University of Isfahan, Iran,

Email sargolzaeis@gmail.com

Received: February 24, 2017| Published: May 24, 2017

\section{Introduction}

Availability of advanced technologies in recent century, motivate some managers and urban plannerstotry using these solutions to increase urban users' quality of life. However, there is not any idea about the technology users' decision in terms of using the advanced technologies. If managers provide the technology, but users of their organizations hesitate to use it or reject it, the technology adoption process will fail. For example, a wide range of cutting edge technologies such as laser scanners are available to professions. ${ }^{1-4}$ However, it is reported that there are barriers to use these technologies in construction sites present the initial results of are search project to give an understanding of the processes, different sources of information and the critical factors that professional organizations are affected, when purchasing advanced technologies..$^{5-8}$ They present a technology adoption model that is verified using the results of observations to a wide range of vendor with different strategies, and user interviews approached in two equipment exhibitions in Australia.

In another discipline, Sargolzaei et al. ${ }^{9}$ argues that the current models suffer to cover city councils' attributes and citizens' concerns in terms of compatibility of the current technologies and functionality of the available technologies. This research seeks to investigate how the process of Technology Acceptance Model (TAM) developed by Davis ${ }^{10}$ can be extended for different contexts. TAM considers different attributes such as the user conditions, communities, and the user perception. In line with the main model, TAM $2,{ }^{11}$ and TAM $3{ }^{12}$ are developed and cited over 11924, and 2367 by scholars, respectively. This research defines the constructs that affect the process of technology adoption. Hence, the following questions are raised in the urban planning context: What constructs are added to TAM in recently developed models, and to which extend the main constructs of basic TAM are related to the context. In the following sections, we discuss three mentioned models and their constructs, respectively.

\section{Discussion}

\section{Review of technology acceptance models}

Some studies indicate that, since the 1980 s about 50 percent of all new capital investment in organizations including professional companies has been in information technology. ${ }^{13}$ Yet, for technologies to improve productivity, they must be accepted and used by users that can be the staff members of external users such as citizens. Explaining user acceptance of new technology is often described as one of the most mature research areas in the contemporary information systems (IS) literature. Research in this area has resulted in several theoretical models, with roots in information systems, psychology, and sociology that routinely explain over 40 percent of the variance in individual perceptions and their intention to use technology. ${ }^{14-16}$ But nowadays technology acceptance models are widely used in different areas such as agriculture, ${ }^{17,18}$ construction, ${ }^{19-22}$ and urban planning. The variety of application of these models shows their importance for the scholars.

\section{Principals and basic model}

TAM was proposed by Davis in 1986 in his doctoral thesis. Since then, it has been tested and extended by many researchers. Overall, TAM was empirically proven successful in predicting about $40 \%$ of a system's use. ${ }^{22,23}$ A key purpose of TAM is to provide a basis for tracing the impact of external variables on internal beliefs, attitudes, and intentions. It suggests that perceived ease of use (PEOU), and perceived usefulness (PU) are the two most important constructs in explaining system use. TAM was tailored to IS contexts, and was designed to predict information technology acceptance and usage on the job. But after that TAM has been widely applied to a diverse set of technologies and users. The final conceptualization of TAM excludes the attitude construct in order to better explain intention parsimoniously.

\section{The extension of TAM}

TAM2 is an extended version of TAM by including some additional predictors by Venkatesh and Davis in 2000. TAM2 reflects the impacts of three interrelated social forces affecting on an individual intention to adopt or reject a new or advanced technology. A wide range of moderators such as: subjective norm, voluntarieness, age, sex, culture and image can be considered in this modeling method. Moreover, the proposed TAM2 encompasses cognitive instrumental processes; job relevance, output quality, result demonstrability, and perceived ease of use as determinants of perceived usefulness and usage intention. Venkatesh and Balacombine TAM2 and the model of the determinants of perceived ease of use,,$^{24}$ and develop an integrated model of technology acceptance, namely TAM3. TAM3 presents a 
complete homological network of the determinants of individuals' IT adoption and use. This model suggests three theoretical extensions beyond TAM 2 and the model of the determinants of perceived ease of use. The constructs of three mentioned models are introduced in next part. ${ }^{25-28}$

Table I Definition of constructs using in different models

\section{Constructs of technology acceptance models}

In this section, definitions of constructs which are used in the above mentioned modelsare presented in Table 1.

\begin{tabular}{|c|c|c|c|}
\hline Model & Reference & Construction & Definition \\
\hline \multirow{2}{*}{$\begin{array}{l}\text { TAM basic } \\
\text { construction }\end{array}$} & \multirow{2}{*}{10} & $\begin{array}{l}\text { Perceived Ease } \\
\text { of Use }\end{array}$ & The degree to which a person believes that using a particular system would be free of effort. ${ }^{10}$ \\
\hline & & $\begin{array}{l}\text { Perceived } \\
\text { Usefulness }\end{array}$ & $\begin{array}{l}\text { The degree to which a person believes that using a particular system would enhance his or her job } \\
\text { performance. }{ }^{10}\end{array}$ \\
\hline \multirow{5}{*}{$\begin{array}{l}\text { TAM2 } \\
\text { additional } \\
\text { constructs }\end{array}$} & \multirow{5}{*}{26} & Subjective Norm & $\begin{array}{l}\text { Individual's perception that most people who are important to him think he should or should not } \\
\text { perform the behavior in question. }{ }^{15}\end{array}$ \\
\hline & & Image & $\begin{array}{l}\text { The degree to which use of an innovation is perceived to enhance one's image or status in one's social } \\
\text { system. }{ }^{18}\end{array}$ \\
\hline & & Job Relevance & $\begin{array}{l}\text { An individual's perception regarding the degree to which the target system is applicable to his or her } \\
\text { job. }{ }^{26}\end{array}$ \\
\hline & & Output Quality & $\begin{array}{l}\text { The degree to which those tasks match their job goals, people will take into consideration how well } \\
\text { the system performs those task. }{ }^{26}\end{array}$ \\
\hline & & $\begin{array}{l}\text { Result } \\
\text { Demonstrability }\end{array}$ & The tangibility of the results of using the innovation including their observability and communicability. ${ }^{18}$ \\
\hline \multirow{6}{*}{$\begin{array}{l}\text { TAM3 } \\
\text { additional } \\
\text { constructs }\end{array}$} & \multirow{6}{*}{25} & $\begin{array}{l}\text { Computer Self- } \\
\text { efficacy }\end{array}$ & The ability of user to perform a specific task/job using the computer based if the user's belive. ${ }^{7}$ \\
\hline & & $\begin{array}{l}\text { Perceptions of } \\
\text { External Control }\end{array}$ & $\begin{array}{l}\text { The degree to which an individual believes that organizational and technical resources exist to support } \\
\text { the use of the system. }{ }^{27}\end{array}$ \\
\hline & & $\begin{array}{l}\text { Computer } \\
\text { Anxiety }\end{array}$ & $\begin{array}{l}\text { The degree of "an individual's apprehension, or even fear, when she/he is faced with the possibility of } \\
\text { using computers". }{ }^{\circ}\end{array}$ \\
\hline & & $\begin{array}{l}\text { Computer } \\
\text { Playfulness }\end{array}$ & The degree of cognitive spontaneity in microcomputer interactions. ${ }^{28}$ \\
\hline & & $\begin{array}{l}\text { Perceived } \\
\text { Enjoyment }\end{array}$ & $\begin{array}{l}\text { The extent to which "the activity of using a specific system is perceived to be enjoyable in its own } \\
\text { right, aside from any performance consequences resulting from system use". }{ }^{\circ}\end{array}$ \\
\hline & & $\begin{array}{l}\text { Objective } \\
\text { Usability }\end{array}$ & $\begin{array}{l}\text { A comparison of systems based on the actual level (rather than perceptions) of effort required to } \\
\text { completing specific tasks. }{ }^{10}\end{array}$ \\
\hline
\end{tabular}

\section{Summary}

The review aims to present the basic models of technology acceptance which can be extended and used in different disciplines. TAM often needs to expand or extend its scope through addition of new related variables to capture the characteristics of a new technology. This implies that the TAM can also utilize context-specific constructs for new advanced technologies in a specific field. The basic TAM has been extended to TAM2, andTAM3 which are more detailed including measurements for two main constructs of ease of use and usefulness. Each of these extensions was motivated by the need to predict the usability of new technologies and to identify and stimulate the use of the technology.

TAM is a basis for technology acceptance models. TAM2 is semideveloped model of TAM, which illustrated the constructs of perceived Usefulness such as subjective norm, image, and job relevance. These types of constructs indicate that using a new technology will be more useful for users who would accept the new technology to use or reject it. The results of studies on technology adoption have shown that there are other constructs affecting Perceived Ease of Use, too. Some of them are computer Self-efficacy, computer Anxiety, and computer Playfulness. So, in TAM3-which is more developed than TAM2- the added constructs illustrates using a new technology will help people to live more easily than before. This developed model needs to be adopted for using in other fields of employing technology such as transportation, urban planning and infrastructure management fields. Developing models of TAM3 would provide a good basis to decision makers and managers in various fields, especially urban managers.

Any specific discipline needs to be treated in different way in terms of motivators, barriers, and other constructions. Therefore, it can be expected that further research should be done in this area using much more specific constructs for an accurate prediction of technology usage.

\section{Acknowledgements}

None.

\section{Conflict of interest}

The author declares no conflict of interest.

\section{References}

1. Sepasgozar S, Lim S, Shirowzhan S, et al. Utilisation of a New Terrestrial Scanner for Reconstruction of As-built Models: A Comparative Study. Proceedings of the International Symposium on Automation and Robotics in Construction. 2015. 
2. Sepasgozar SM, Lim S, Shirowzhan S. Implementation of Rapid Asbuilt Building Information Modeling Using Mobile LiDAR. Paper presented at the Construction Research Congress 2014. 2014.

3. Sepasgozar SME, Forsythe P, Shirowzhan S, et al. Scanners and Photography: A Combined Framework. Paper presented at the AUBEA 2016: Proceedings of the $37^{\text {th }}$ Annual Australasian Universities Building Education Association conference. Cairns, Australia; 2016.

4. Sepasgozar S, Bliemel M, Bemanian M. Discussion of Barriers of Implementing Modern Methods of Construction. Journal of Management in Engineering. 2015:32(2).

5. Sepasgozar SME, Bernold LE. Factors Influencing Construction Technology Adoption. Paper presented at the $19^{\text {th }}$ CIB World Building Congress, Brisbane 2013: Construction and Society. Brisbane; 2013.

6. Sepasgozar SME, Loosemore M, Davis SR. Conceptualising information and equipment technology adoption in construction A critical review of existing research. Engineering, Construction and Architectural Management. 2016;23(2):158-176.

7. Compeau DR, Higgins CA. Computer self-efficacy: Development of a measure and initial test. MIS quarterly. 1995;19(2):189-211.

8. Sargolzaei S, Sepasgozar SME, Mojtahedi M. Modeling Urban Technology Acceptance: Factor Analysis Approach. Paper presented at the $16^{\text {th }}$ International Conference on Construction Applications of Virtual Reality. Hong Kong; 2016.

9. Derpsch R, Friedrich T, Kassam A, et al. Current status of adoption of no-till farming in the world and some of its main benefits. Int J Agric \& Biol Eng. 2010;3(1):1-25.

10. Davis FD. Perceived Usefulness, Perceived Ease of Use, and User Acceptance of Information Technology. MIS quarterly. 1989;13(3):319340 .

11. Venkatesh V. Determinants of perceivedease of use: Integrating control, intrinsic motivation, and emotion into the technology acceptance model. Information systems research. 2000;11(4):342-365.

12. Venkatesh V, Bala $H$. Technology acceptance model 3 and a research agenda on interventions. Decision sciences. 2008;39(2):273-315.

13. Westland JC, Clark T. Global Electronic Commerce: Theory and Cases. Cambridge: MIT Press; 2000. 592 p.

14. Faqih KM, Jaradat MIRM. Assessing the moderating effect of gender differences and individualism-collectivism at individual-level on the adoption of mobile commerce technology: TAM3 perspective. Journal of Retailing and Consumer Services. 2015;22:37-52.

15. Fishbein M, Ajzen I. Belief, Attitude, Intention and Behavior: An Introduction to Theory and Research. USA: Penn State University Press; 1975. 10(2):130-132.
16. Legris $\mathrm{P}$, Ingham $\mathrm{J}$, Collerette $\mathrm{P}$. Why do people use information technology? A critical review of the technology acceptance model. Information \& management. 2003;40(3):191-204.

17. Mondal P, Basu M. Adoption of precision agriculture technologies in India and in some developing countries: Scope, present status and strategies. Progress in Natural Science. 2009;19(6):659-666.

18. Moore GC, Benbasat I. Development of an instrument to measure the perceptions of adopting an information technology innovation. Information systems research. 1991;2(3):192-222.

19. Sargolzaei S, Sepasgozar SME, Moradi M. Intention to Use New Technologies in Urban Management: An Application and Extension of the Technology Acceptance Model for Paper presented at the international conference on research in science and technology. kualalumpur-Malaysia; 2015.

20. Sepasgozar SM, Davis SR. A Decision Framework for Advanced Construction Technology Adoption. Paper presented at the Transportation Research Board 94 ${ }^{\text {th }}$ Annual Meeting. 2015.

21. Sepasgozar SME, Bernold LE. A Technology pre-adoption model for construction. Paper presented at the $37^{\text {th }}$ Annual Conference of Australasian University Building Educators Association (AUBEA). Sydney; 2012.

22. Sepasgozar SME, Lim S, Shirowzhan S, et al. Implementation of As-Built Information Modelling Using Mobile and Terrestrial Lidar Systems. The $31^{\text {st }}$ International Symposium on Automation and Robotics in Construction and Mining (ISARC 2014). Sydney; 2014.

23. Sepasgozar SME, Razkenari MA, Barati K. The Importance of New Technology for Delay Mitigation in Construction Projects. American Journal of Civil Engineering and Architecture. 2015;3(1):15-20.

24. Taylor S, Todd PA. Understanding information technology usage: A test of competing models. Information systems research. 1995;6(2):144 176.

25. Venkatesh V. Determinants of perceivedease of use: Integrating control, intrinsic motivation, and emotion into the technology acceptance model. Information systems research. 2000;11(4):342-365.

26. Venkatesh V, Davis FD. A Theoretical Extension of the Technology Acceptance Model: Four Longitudinal Field Studies. Management Science. 2000;46(2):186-204.

27. Venkatesh V, Morris MG, Davis GB, et al. User Acceptance of Information Technology: Toward a Unified View. MIS quarterly. 2003;27(3):425-478.

28. Webster J, Martocchio JJ. Microcomputer playfulness: Development of a measure with workplace implications. MIS quarterly. 1992;16(2):201226. 